\title{
Issues and Problems in Higher Education from the Perspective of India and Canada
}

\author{
Anjali Khirwadkar \\ Department of Education, Faculty of \\ Education and Psychology, The Maharaja \\ Sayajirao University of Baroda, \\ Vadodara, Gujarat, India
}

\author{
Pinkal Chaudhari \\ UGC-JRF, CASE, Faculty of Education \\ and Psychology, The Maharaja Sayajirao \\ University of Baroda, Vadodara,Gujarat, \\ India
}

\begin{abstract}
Globalisation is a phenomenon that is transforming the world economic system including nearly all aspects of production, distribution and other business processes. Globalisation has changed scenario of Education too. Every nation has its specific thrust areas for the development of nation depending upon the requirement of the country. Education is one of the thrust areas for the development of the country economically, technologically and politically. Education system of any nation bridges the gap between the people of different community, Caste, Gender etc. Countries have their own provision in terms of policies and practices at university level. In India there is a National policy of Education (NPE, 1986) and Program of Action (POA 1992) and five year developmental plan along with National assessment and Accreditation Council to maintain quality in higher education and at the same time to bring measures for equity and equality in higher education. Similarly in a developed country like Canada, there is Council of Ministers of Education Canada (CMEC) actively engaged for minimizing gap between social barriers like gender, culture etc. Though there is vast difference between countries like Canada and India in terms of Geographical area, Population, Language, literacy rate etc. it would be interesting to study the issues and problems faced by higher education and teacher education in particular of both the countries. In this paper authors have discussed comparative scenario of higher education and in particular teacher education in Canada and India in terms of quality input.
\end{abstract}

\section{Introduction}

Higher Education is a pioneer of National Economy. Quality of Education especially higher education develops skilled manpower with knowledge economy through which nation will grow. Due to Globalisation and Liberalization, there is an increasing competition from developed and developing nations and with the possibility of locating educational operations anywhere in the world. In every nation have their educational policy and action Plans along with Educational assessment and Accreditation criteria to maintain quality in higher education. The Nations need to invest in Teacher education to equip youth to compete at the leading edge of economic activity because all discipline emerge from education and education emerge from quality teacher education.

The knowledge-based society is distinguished by placing emphasis on precognition and adaptation to nationalization to globalisation of education. Knowledge based society stresses on Quality education system to bridging the gap between the people of different community, Caste, Gender etc. Thus, it is essential to redirect Higher education and teacher education in terms of goals, purposes, and Approaches to move from nationalization to globalisation.

\section{Education Scenario in India}

India is the seventh largest country in the world with the population of Population of 121 Billion. The country covers an area of 3.28 million sq kilometer. The mainland of India extends between $8^{\circ} 4^{\prime} \mathrm{N}$ and $37^{\circ} 6^{\prime}$ North Latitude and $68^{\circ}$ $7^{\prime}$ and $97^{\circ} 25^{\prime}$ East Longitudes. There are as many as 28 states in India. Hindi is the National Language [6] [10].

Education in India is provided by the public sector as well as the private sector. Education in India falls under the control of both the Union Government and the states, with some responsibilities lying with the Union and the states having autonomy for others. Most universities in India are controlled by the Centre or the State Government. 
After passing the Higher Secondary Examination (grade 12 examination), students may enroll in general degree programs such as bachelor's degree in arts, commerce or science, or professional degree programs such as engineering, law or medicine. After High school, student can enroll in teacher education or after graduation or Post graduation; student can enroll in Teacher education. The main governing body at the tertiary level is the University Grants Commission which enforces its standards, advises the government, and helps coordinate between the Central and the state. India's higher education system is the second largest in the world, after China and the United States is after India as shown in Figure 1.

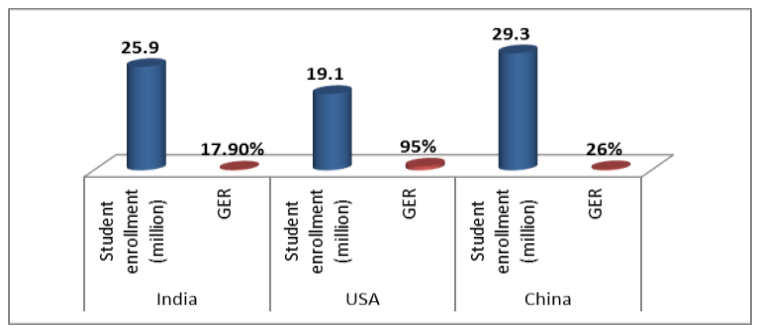

Source: FICCI, 2012

Figure 1. Students' Enrolment in Higher Education

Table 1. Population of India in age group of 18-24 years

\begin{tabular}{|l|l|}
\hline Year & Percentage \\
\hline 2001 & $11 \%$ \\
\hline 2011 & $12 \%$ \\
\hline
\end{tabular}

Source: Census, 2011

In the year $2001,11 \%$ of population of the country was in age group of 18-24 years which is raised to $12 \%$ by the 2011 as indicated in Table 1 [10]. This young population is an invaluable asset which if equipped with knowledge and skills, can contribute effectively to the development of the national as well as the global economy. The Indian Higher education system is plagued by three basic challenges viz., access, equity and quality. These issues are important for the country, as it is now engaged in the use of higher education as a powerful tool to build a knowledge-based information society of the $21^{\text {st }}$ Century. Hence, the three pillars of education are expansion, inclusion and excellence.

\section{Higher Education in India}

Today the world economy is experiencing an unprecedented change. New developments in science and technology, media revolution internationalization of education and the ever expanding competitive environment are governing the educational scenario. Because of interdependence and integration of world economy in recent years, the Indian higher education system has a new role and a challenge to provide to the nation and the world at large in providing skilled human power at all levels, and having breadth of knowledge and confidence to effectively confront the social and economic realities. It is true that enhancing social access to higher education is still important in the country like India. But, the major challenge before the Indian higher education system is to bring equity and quality in higher education.

Source: FICCI, 2012

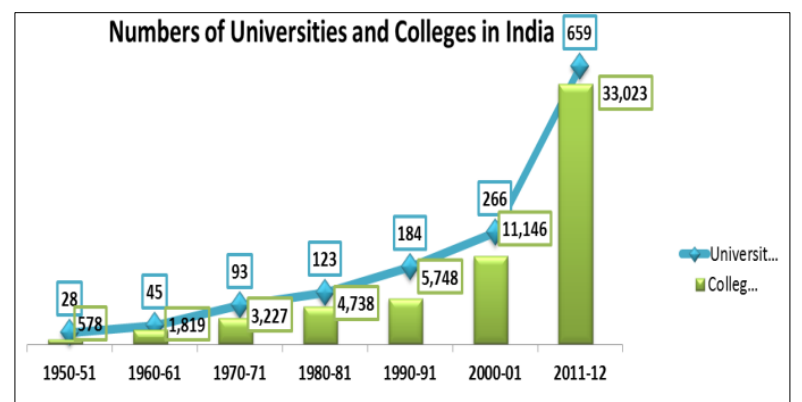

Figure 2. Number of Universities and Colleges in India

The higher education system in India has grown in a remarkable way, particularly in the postindependence period, to become one of the largest systems of its kind in the world. There are around 659 Universities and 33,023 Colleges so far upto 2011-12 and Total Enrolment in Higher education was 18.5 million [5].

Table 2. Number of Central, State and Private Universities and Colleges in India

\begin{tabular}{|l|l|l|}
\hline & $\begin{array}{l}\text { University- } \\
\mathbf{6 5 9}\end{array}$ & $\begin{array}{l}\text { Colleges } \\
\mathbf{3 3 , 0 2 3}\end{array}$ \\
\hline Central & 152 & 669 \\
\hline State & 316 & 13,024 \\
\hline Private & 191 & 19,930 \\
\hline Enrollment in 2012 & \multicolumn{2}{|c|}{ 18.5 million } \\
\hline
\end{tabular}

Higher education enrollment has grown at a healthy pace, with 3.6 million students being added over the last four years [12] [21].The Gross Enrollment Ratio (GER) currently stands at $13.8 \%$, up from $11 \%$ in 2005 . The GER has increased over the last decade at a CAGR of $3.3 \%$. With a GER of $13.8 \%$ and enrollment of 14.6 million, access to 
higher education in India is currently restricted to a limited population [9].

There is wide disparity in Higher Education GERs across states, urban and rural areas, gender, and communities as indicated in Table 3.

Table 3. Disparity in Higher Education GERs

\begin{tabular}{|c|c|c|c|c|}
\hline \multirow{2}{*}{ Inter state disparity } & \multicolumn{2}{|c|}{ Delhi } & \multicolumn{2}{|c|}{ Assam } \\
\cline { 2 - 4 } & \multicolumn{2}{|c|}{$31.9 \%$} & \multicolumn{2}{|c|}{$8.3 \%$} \\
\hline Urban-rural divide & Urban area & \multicolumn{2}{c|}{ Rural area } \\
\cline { 2 - 4 } & $23.8 \%$ & \multicolumn{2}{|c|}{$7.5 \%$} \\
\hline \multirow{2}{*}{$\begin{array}{c}\text { Differences across } \\
\text { communities }\end{array}$} & SCs & STs & OBCs & Others \\
\cline { 2 - 4 } Gender disparity & \multicolumn{2}{|c|}{ Female } & $6.5 \%$ & \multicolumn{2}{|c|}{ Male } \\
\cline { 2 - 4 } & \multicolumn{2}{|c|}{$10.6 \%$} & \multicolumn{2}{|c|}{$14.4 \%$} \\
\hline
\end{tabular}

Source: FICCI, 2011

Other factor with regard to quality of Indian Higher education is faculty shortage at higher education level. There are about $45 \%$ of the positions for professors, $51 \%$ positions for readers, and $53 \%$ positions for lecturers were vacant in Indian universities in 2007-08. Further the poor academic standards as the system are plagued with outdated curricula and ill-equipped libraries and laboratories.

The number of students enrolled in Classes 912 , which is an indicator of potential demand for higher education, has increased at a CAGR of 5.7\% over 1996-2008, in line with the growth in higher education enrollment with the implementation of RTE Act. Although Higher Education has expanded several times since independence, the major issues of access, equity, and quality continue to be areas of concern.

\subsection{Government Initiatives to tackle the above Issues}

The Yashpal Committee Report talked about the concept of a university as a place where research and teaching become two important pillars of the creation of knowledge and should go together [21]. It should provide practical training to the people that should be based on new knowledge and in response to social and personal needs. Most importantly, university should allow for the diverse growth of knowledge and should not lead to fragmentation of knowledge. It is, therefore, recommended that normally, no single discipline or specialized university should be created. There is also an idea that undergraduate programs should be restructured to enable students to have opportunities to access all curricular areas with fair degree of mobility [21].
Improving access to Higher education, quantitative expansion in enrolment will be achieved through expansion of existing institutions, both government and private; creation of new government (Central and States) funded universities and colleges; facilitating/ removing barriers in creation of new universities and colleges; special programmes for targeted expansion in Central Universities; incentivizing State universities and colleges.

These are general recommendations given by Moily Committee (2006), National Knowledge Commission (2006) for improving Equity, equality and Quality in Higher Education like-[11] [13]

- Expand access by supporting existing institutions, establishing new Central Higher Education Institutions like IITs, NITs, IIITs, IISERs, IIMs ,SPAs

- Globalisation of Education, Permitting Private institutions

- Adopting Open learning, Online learning, Distance learning.

- Professional Skill development.

- Promote the quality of higher education by investing in infrastructure and faculty, promoting academic reforms, improving governance and institutional restructuring.

- More focus given on Research.

- Increase accessibility of all curricular areas with fair degree of mobility.

- The setting up of Central Universities, with high quality of infrastructure for teaching and research.

Government initiated few Schemes for the upliftment of the Standard of Higher Education like [21]:

- National Mission in Education through ICT.

- Professional Development of Faculty.

- Technical Education Quality. Improvement Programme (TEQIP) -II

- Innovation Universities.

- Review of Institutions Deemed to be Universities.

- National database of academic qualifications.

Department of Higher Education $\left(\mathrm{XI}^{\mathrm{TH}}\right.$ Five Year Plan: 2007-2012) has proposed following areas of concern:

I. Provide greater opportunities of access to higher education with equity to all the eligible persons and in particular to the vulnerable sections. 
II. Expand access by supporting existing institutions, establishing new institutions, supporting State Governments and NonGovernment Organizations/civil society to supplement public efforts.

III. removing regional or other imbalances that exist at present.

IV. Initiate policies and programmes for strengthening research and innovations and encourage institutions - public or private - to engage in stretching the frontiers of knowledge.

V. Skilled development so as to reap the benefits of the demographic advantage of the country.

VI. Promote the quality of higher education by investing in infrastructure and faculty, promoting academic reforms, improving governance and institutional restructuring.

VII. Engage with civil society, state governments and with the international community in furtherance of knowledge, language and culture.

Looking forward to progress under Eleventh Five year Plan (2007-2012). Few steps has been taken for the Higher education under12th Five Year Plan (2012-2017) like [9][10] [15]:

- Spending to be raised from 1.1 to $1.5 \%$ of GDP (INR 250 billion)- for state universities, scholarship, etc.

- Increase expenditure on research to $2 \%$ of GDP.

- Entry of foreign education provider

- Creation of teaching resources through leveraging information technology.

These are general recommendations given by Government of India for improving Equity, equality and Quality in Higher Education. Government initiatives to improve equity and equality are further discussed below

3.1.1. Reservation policy in India: In 1982, the Constitution specified $15 \%$ and $7.5 \%$ of vacancies in public sector and government-aided educational institutes as a quota reserved for the SC and ST candidates. In 1990, Prime Minister V. P. Singh announced that $27 \%$ of government positions would be set aside for OBC's in addition to the $22.5 \%$ already set aside for the SCs and STs [4].

The share of Scheduled Castes and Scheduled Tribes enrolment as a percent to total enrolment in higher education has been steadily increasingover the years in Technical Education, Science Education and Doctoral Education also. Several schemes of UGC support the education of SCs and
STs like remedial coaching at UG and PG level, coaching classes for preparation for National Eligibility Test (NET), coaching classes for entry in services, postgraduate scholarships, establishment of centres in universities for study of social exclusion and inclusive policy.

3.1.2. Education of Girls: Gender parity index has shown continuous improvement over the years as a result of Government's efforts to increase women participation. Women representation is increasing, though still low in faculties like, law, medicine, education, veterinary science etc. UGC have launched a number of schemes to achieve gender equity. Day care centres in universities and colleges provide day care facility on demand basis for children of 3 months- 6 years of age. There is the provision of India Gandhi Scholarship for single girl child for pursuing higher and technical education. Construction of girls' hostel for colleges is supported by UGC. To promote higher studies Post-Doctoral fellowships are offered for women.

3.1.3. Persons with Disabilities: The Department of Higher Education has taken several initiatives to promote higher/professional education among the persons with disabilities. UGC has integrated schemes such as Teacher Preparation in Special Education (TEPSE) and Higher Education for Persons with Disabilities (HEPSN) to support differently abled persons in higher education. All India Council for Technical Education (AICTE) also has a scheme of tuition fee waiver for physically challenged. UGC has furthermore issued several guidelines to the universities including 3 percent reservation.

3.1.4. Educational Advancement of Minorities: For inclusive development of higher education, educational advancement of students belonging to minority communities is a point of focus. New Model Degree Colleges being established in districts with Gross Enrolment Ratio (GER) lower than the National average in higher education include 90 districts having minority concentration. Under the Sub-Mission on Polytechnics, the Government of India provides Central financial assistance to the State Governments/UTs for setting up of polytechnics in the un-served and underserved districts during the XI Plan.

The Central Government is conscious of the need to raise both the enrolment rate and access to higher education to all who deserve irrespective of class, caste, religion, gender or economic status. There are proposals for improving access to quality 
higher education to disadvantaged groups in the population [11] [16].

\section{Background Context of Post Secondary Education in Canada}

Canada has federation of ten provinces and three territories. It has population of $33,476,688$ with 97 per cent literacy rate. With a geographic area of $9,970,610 \mathrm{~km}^{2}$, it is the second largest country in the world in this respect. Canada has two official languages: French and English [21].

In Canada, post-secondary education is the responsibility of provincial and territorial governments, and in each province and territory there are laws, policies and procedures that govern the operation of post-secondary institutions. Canada is one of the world's top education performers and among the top 3 Organization for Economic Cooperation and Development (OECD) countries in spending per capita on public postsecondary education. More than 200,000 international students chose Canada in 2011.Canada has 4 universities in the top 100 of the Shanghai World University Rankings [4].

\section{Access, Equity and Quality Concern for Canadian Higher Education}

The latest Programme for International Student Assessment (PISA) results is that Canada continues to be marked by high achievement and high equity in education. This means that the impact of socioeconomic status is relatively small, and the gap between the high achievers and low achievers is also small, compared to most other countries. In comparison to other countries, the gradient of inequality in attainment is relatively low, $54 \%$ have tertiary education, compared to the international average of $32 \%$ [8].

Following the large loss of jobs during the recession, many Canadians returned to school for education and training. This, combined with a large cohort of high school graduates, has produced one of the largest classes of post-secondary students in Canada's history. While students continue to pursue higher education, the saddling of a generation with billions of dollars in debt will have implications for Canada's economy and socioeconomic equality [3].

There are around 256 Higher Education Universities in Canada. As per table 4, participation of young students between age group of 18-24 in university education grew from $12 \%$ in $1972-1973$ to $23 \%$ in $2008-200925 \%$ in $2011-12$ [3] [4].

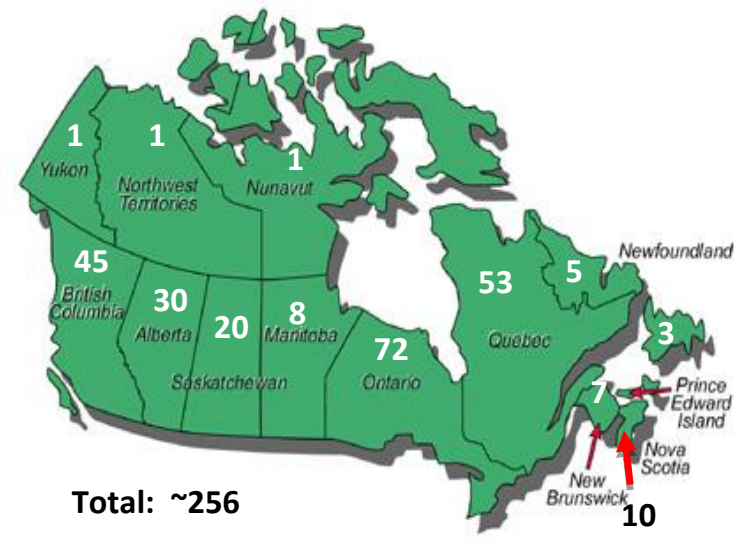

Figure 3. Province wise Universities in Canada

Provincial funding rules are also geared to squeezing more students into the classrooms rather than improving the quality of the education that is delivered, and support uniformity of product rather than differentiation and specialization of universities into different areas or missions.

Table 4. Participation of Young Students in University

\begin{tabular}{|c|c|}
\hline Year & Percentage \\
\hline $\mathbf{1 9 7 2 - 1 9 7 3}$ & $12 \%$ \\
\hline $\mathbf{1 9 9 2 - 1 9 9 3}$ & $17 \%$ \\
\hline
\end{tabular}

Source: CME, 2012

There is also a large number of older faculty at Canadian colleges and universities who will be retiring over the next decade and the Canadian postsecondary education system is simply not producing enough replacements for them. Where the needed new faculty will be found is a very severe problem that has not at all been adequately planned for.

\section{Issues regarding Educational System of Canada}

In the absence of national policies for postsecondary education, provincial policies dealing with access and funding have diverged dramatically from one another. Across the country, students face significantly different challenges to pursuing higher education. In addition, Aboriginal learners across Canada continue to be marginalized within the post-secondary education system, with enrolment rates significantly below peer groups from non-Aboriginal populations in spite of 
marked population growth in Aboriginal communities [3].

The major problems facing higher education and Teacher Education in Canada, and the motivation for the research studies appearing, can be gathered under four broad headings: underfunding, student access, Quality education and faculty shortage.

\subsection{Underfunding}

Funding shortfall under which the postsecondary sector and especially universities in Canada have been operating for more than a decade now. Per-student spending as a percentage of the GDP is generous but not outstanding, by international standards. Provincial funding transfers to universities and colleges have significantly declined in real (inflation-adjusted) per-student [4].

Under the current structure for federal transfer payments, provincial governments are free to do as they wish with the funding they receive. Increment in the Tuition Fees and problems of EPF resulted into overcrowded classes, numbers of full-time faculty declined, student-faculty ratios have shot up dramatically, and methods of teaching have shifted to accommodate large student numbers, so that quality of undergraduate education has noticeably declined.

As per Ontario Confederation of University Faculty Associations (OCUFA) faculty survey (2012) - 83 per cent of faculty have budget constraints that indicate that their departments have faced budget cuts. It is also clear that constrained budgets are leading to larger class sizes (77 per cent), hiring freezes (76 per cent), increased use of part-time or sessional faculty (76 percent), delayed maintenance of older facilities (64 per cent), and fewer course choices (53 per cent) [14].

\subsection{Accessibility}

The second broad set of issues that needs to be addressed revolves around student access and affordability of a postsecondary education. There is some reason for hope that the private sector, recognizing its stake in higher education, will develop new means to assist students.

According to Education Indicators in Canada: An International Perspective, 2009 figures for highest level of education attained indicate that about half of the population aged 25 to 64 have successfully completed a program of postsecondary education. The increase was much larger for women than for men.
Table 5.Agewise population that has attained postsecondary education, Canada, 2009

\begin{tabular}{|c|c|c|c|c|c|}
\hline & $\begin{array}{c}\mathbf{2 5}-\mathbf{6 4} \\
\text { Years }\end{array}$ & $\begin{array}{c}\mathbf{2 5}-\mathbf{3 4} \\
\text { Years }\end{array}$ & $\begin{array}{c}\mathbf{3 5}-\mathbf{4 4} \\
\text { Years }\end{array}$ & $\begin{array}{c}\mathbf{4 5}-\mathbf{5 4} \\
\text { years }\end{array}$ & $\begin{array}{c}\mathbf{5 5}-\mathbf{6 4} \\
\text { years }\end{array}$ \\
\hline College & 24 & 26 & 27 & 24 & 20 \\
\hline University & 25 & 30 & 29 & 21 & 21 \\
\hline Total & 49 & 56 & 56 & 45 & 41 \\
\hline
\end{tabular}

Table 6 below details the postsecondary attainment of various age groups. In addition, another 12 per cent have certificates or diplomas from vocational schools or apprenticeship training.

Table 6. Rates of access to college and university for minority groups, all provinces

\begin{tabular}{|c|c|c|c|}
\hline & ollege & University & Any \\
\hline \multicolumn{4}{|c|}{ Immigrant status } \\
\hline $\begin{array}{l}\text { First-generation } \\
\text { immigrant }\end{array}$ & 29.6 & 57.0 & 86.6 \\
\hline $\begin{array}{l}\text { Second-generation } \\
\text { immigrant }\end{array}$ & 30.0 & 53.0 & 83.0 \\
\hline Non-Immigrant & 34.2 & 37.0 & 71.2 \\
\hline \multicolumn{4}{|c|}{ Aboriginal status } \\
\hline Aboriginal & 28.0 & 23.1 & 51.1 \\
\hline Non-Aboriginal & 33.2 & 42.2 & 75.4 \\
\hline
\end{tabular}

Education's place as a right for Aboriginal peoples comes from a series of treaties signed over the course of several decades and is recognised in Canada's Constitution. Aboriginal populations showed much lower levels of access to and graduation from university than the non-Aboriginal population, but have similar rates of college completion. The ministers responsible for education in the provinces and territories, working together as the Council of Ministers of Education, Canada (CMEC), have identified Aboriginal education as one of the key activity areas of education. High and rapidly increasing tuition fees limit access to post-secondary education for students from low- and middle-income backgrounds. At their current rate of increase, tuition fees are estimated to outpace all other student expenses combined in 15 years [3].

\subsection{Quality of Education}

The Commission of Inquiry on Canadian University Education observed that historical consciousness is one of the accepted goals of higher education [1]. The fact that Canada has fewer engineers per capita than the United States or Japan may reflect the degree of emphasis this country has placed on science education [1]. 
According to OCUFA surveyed faculty - 42 per cent - believe that the quality of undergraduate education has declined due to public funding and rising enrolment, larger class sizes, reduced student-faculty interaction, and deteriorating labs, libraries and classrooms and 26 per cent believe that the quality of graduate education has declined, professors and librarians appear less concerned about graduate studies than the undergraduate experience [14]. 43 per cent of faculty believes that they do not have the resources they need to provide a high quality education to their students. This suggests that strained university budgets are increasingly unable to cope with the rising number of students in Ontario [14].

\subsection{Faculty Shortage}

According to OCUFA surveyed faculty - 63 per cent indicate that the first priority for any new funding should be allocated to new full-time faculty hires [14]. This reflects the widespread belief that universities do not have sufficient fulltime faculty to cope with rising student demand. The major concern is the challenge of faculty renewal over the next decade [14].

Investment in graduate studies provides the foundation for long-term innovation and trains the highly skilled teachers and researchers that are needed to respond to the economic and social challenges Canada faces now and in the future.

As the economy prospered and offered lots of jobs to university graduates, fewer students carried on for doctoral training with an eye for academic work. In order to be sustainable without continuing severe declines in quality, clearly greater resources need to be directed to the operations of the postsecondary education sector in Canada.

\section{Government Initiatives to tackle the above Issues}

All provinces have made efforts to make education more accessible to students with physical or developmental disabilities. Some jurisdictions have attempted to integrate most special needs students, although it has been suggested that discussion of the quality of their education, a crucially important issue for these groups, as it is for all students, has been "largely avoided."

Following are the recommendations to increase quality of Higher education [2] [3] [4] [8].

- The federal government should implement a federal Post-Secondary Education Act
- Increase in the number of Graduate Scholarships.

- Availability of affordable Students' Loan

- The determination to approach the training of teachers with an ethos of the holistic rather than technical operative at its core.

- Recent federal research funding should be concentrated in the science/technology/medical areas.

- Federal Government and Province give focus on following aspect to increase quality of Higher Education.

- Meeting Diverse Needs of the learner, emphasizing, Computer Education, Official Languages in Education, Proposal of Internationalization

- Increase standard of Research

- to encourage measures that remove barriers to post-secondary education due to socioeconomic status.

- Government should invest in making college and university more affordable.

- Fulfill Canada's obligations: fund aboriginal education.

The long-term policy of the federal government amounts to a gradual withering away of EPF support for post-secondary education, it should concentrate on financing research at post-secondary institutions and encourage university ties with industry, in order to promote Canada's global competitiveness [7]. Replacement of the program with a new Income-Contingent Repayment Student Assistance Plan. It would make loans widely accessible, and repayable as a surtax; thus, by linking repayment to earnings [1].

Rapid developments in all spheres of life, changing workplace requirements and complex bilingual and multicultural society create demands for a wider range of educational programs. Few recommendations suggested are described as follow [4]:

Diverse Needs:

An increasingly mobile workforce has differences in requirements and course material, teaching methods and age of mandatory attendance. Even greater differences exist at the university level, where students often experience difficulties in transferring from one autonomous institution to another.

\section{Computer Education}

Technological change has created a need for a new kind of learning, "computer literacy," and has introduced new methods of program delivery. Computer competence has become an educational goal recognized by the inclusion of relevant 
programs in curricula. Teachers should be trained to use computers in their instruction, and that the use of computer-based approaches in literacy and skills upgrading be encouraged.

\section{Official Languages in Education:}

The quality and accessibility of second language education, however, is uneven across the country. The federal government provides costsharing support for education in the language of the official language minorities and for opportunities to learn a second official language. Federal spending priorities in recent years have also included the expansion of post-secondary services in French and appropriate teacher-education programs.

\section{Proposal of Internationalization:}

OECD has declared that "internationalization," a process of integrating an international dimension into university functions, should be the new emphasis in higher education. Among other things, this process calls for curriculum changes to incorporate the experiences and knowledge sources of other countries and give students the opportunity to become "globally literate citizens." In recent years, some Canadian universities have been working toward this end.

National is struggle with pockets of economic boom and others of disparity, Higher education need to be critically understood adaption to emergent needs, of both the individual and the communities served, from the local to the global. Teacher preparation needs to be adaptable to the contexts in which its candidates serve while providing grounding in key areas of knowledge.

\section{Conclusion}

In order to bridging the gap between Nationalization and globalisation of education and learning, challenges and opportunities of the Information Age, requires raising the efficiency of the existing systems of education. Graduates of Higher education and Teacher education of these systems, to varying degrees, now find themselves deficient in knowledge as well as cognitive skills that are necessary for the increasingly sophisticated environment and for the ever-evolving labor market. There is a general understanding is required to understand the needs of the nations to be responsive to ongoing change in an era of "globalization" and "a knowledge economy".

\section{References}

[1] Association of Universities and Colleges of Canada, Report of the Commission of Inquiry on Canadian University Education, AUCC, Ottawa, 1992.
[2] Canadian Association of University Teachers, Canada Post-secondary education act: Bill C-X, CAUT, Ottawa. 2007.

[3] Canadian Federation of Students, Public education for the Public good: a national vision for Canada's postsecondary education system, CFS, Ottama, 2010.

[4] Council of Ministers of Education, Canada, Canada's post-secondary education system. Promoting Equality of Educational Opportunity: Canada Report for the UNESCO Eighth Consultation of Member States on the Implementation of the Convention and Recommendation against Discrimination in Education. Canadian Commission for UNESCO, Ontario, 2012.

[5] FICCI. Higher Education in India: Twelfth Five Year Plan (2012-2017) and beyond. Kolkata: Ernst \& Young Pvt. Ltd, 2012.

[6] Geography of India, From http://www.mapsofindia. com/geography/, $12^{\text {nd }}$ May, 2012.

[7] H. McKenzie, Education in Canada: Current Issues. Political and Social Affairs Division.publications.gc.ca/CollectionR/LoPBdP/BP/bp3 86-e.htm, 1994.

[8] M. Illingworth, Education in the Age of the Information Superhighway: An Investigation into Initial Teacher Training in Canada, Canadian Journal of Education (3), 2012, pp. 180-193.

[9] MHRD, Report to the People on Education. MHRD, New Delhi, 2010.

[10] Ministry of Home Affairs, Census 2011. Government of India, New Delhi, 2011.

[11] Moily Committee, Final Report on the Oversight Committee on the implementation on the new reservation Policy in Higher educational Institutions, oversight committee.gov.in/ocrep.pdf, Sep 30, 2006.

[12] National Center of Education Statistics, Ministry of Education of the People's Republic of China, http://www.moe.edu.cn/publicfiles/business/htmlfiles/mo e/moe_2792/index.html, 2008.

[13] National Knowledge Commission, National Knowledge Commission Report to the Nation 2006 2009, New Concept Information Systems Pvt. Ltd., New Delhi, 2009.

[14] Ontario Confederation of University Faculty Associations, OCUFA Faculty Survey: Views on university quality and faculty prioritie, 2012.

[15] Planning Commission, Eleventh Five Year Plan (2007-2012), Government of India, http://planningcommission.nic.in/plans/planrel/11thf.htm , 2012. 
[16] Social, Economic and Educational Status of the Muslim Community of India, MHRD, Govt. of India, 2009.

[17] S. K. Jangir, Reservation Policy and Indian Constitution in India, American International Journal of Research in Humanities Arts and Social Sciences, 3(1), 126-128, 2013.

[18] Statistics Canada, Canada Census, www.statcan.gc.ca, $3^{\text {rd }}$ January, 2013.

[19] University Grant Commission, Higher education in India: Issues, Concerns and New Directions, UGC, New Delhi:, 2003.

[20] University Grant Commission, UNESCO Global Education Digest 2010, MHRD Annual Report 2009-10, US Department of Education, MHRD, 2011.

[21] Yash Pal Committee, Report of 'The Committee to Advise on Renovation and Rejuvenation of Higher Education, MHRD, 2009. 